Correspondence to: Professor M.I. Bruce

Department of Chemistry

University of Adelaide

Adelaide

South Australia 5005

Fax: $\quad+61883034358$

E-mail:michael.bruce@adelaide.edu.au

\title{
Alkynyl and poly-ynyl derivatives of carbon-tricobalt clusters
}

\author{
Alla B. Antonova, ${ }^{\mathrm{a}, \mathrm{b}}$ Michael I. Bruce, ${ }^{a}$ Paul A. Humphrey, ${ }^{\mathrm{a}}$ M. Gaudio, ${ }^{a}$ B.K. Nicholson, ${ }^{c}$ \\ Nancy Scoleri, ${ }^{a}$ Brian W. Skelton, ${ }^{d}$ Allan H. White, ${ }^{d}$ Natasha N. Zaitseva ${ }^{a}$ \\ ${ }^{a}$ Department of Chemistry, University of Adelaide, Adelaide, South Australia \\ ${ }^{b}$ Siberian Branch of Russian Academy of Sciences, Krasnoyarsk, Russia \\ ${ }^{c}$ Department of Chemistry, University of Waikato, Hamilton, New Zealand \\ ${ }^{d}$ Chemistry M313, School of Biomolecular, Biomedical and Chemical Sciences, \\ University of Western Australia, Crawley, Western Australia 6009 \\ Email: michael.bruce@adelaide.edu.au
}




\section{Summary}

A series of alkynyl-tricobalt carbonyl clusters, $\mathrm{Co}_{3}\left(\mu_{3}-\mathrm{C}_{\mathrm{n}} \mathrm{R}\right)(\mu$-dppm $)(\mathrm{CO})_{7}\left[\mathrm{R}=\mathrm{Bu}^{\mathrm{t}}, \mathrm{Ph}\right.$, $\left.\mathrm{C}_{6} \mathrm{H}_{4} \mathrm{I}, \mathrm{C}_{6} \mathrm{H}_{4} \mathrm{C} \equiv \mathrm{CH}, \mathrm{SiMe}_{3}, \mathrm{Fc}, \mathrm{Au}\left(\mathrm{PPh}_{3}\right)\right]$ containing three, five or seven carbons in the chain, has been prepared by elimination of phosphine-gold(I) halides in reactions between $\mathrm{Co}_{3}\left(\mu_{3}-\mathrm{CBr}\right)(\mu-\mathrm{dppm})(\mathrm{CO})_{7}$ and $\mathrm{Au}(\mathrm{C} \equiv \mathrm{CR})\left(\mathrm{PPh}_{3}\right)$ or between $\mathrm{Co}_{3}\left\{\mu_{3}-\right.$ $\left.\mathrm{CC} \equiv \mathrm{CAu}\left(\mathrm{PR}_{3}\right)\right\}(\mu-\mathrm{dppm})(\mathrm{CO})_{7}(\mathrm{R}=\mathrm{Ph}, \mathrm{tol})$ and $\mathrm{IC} \equiv \mathrm{CR}^{\prime}\left(\mathrm{R}^{\prime}=\mathrm{SiMe}_{3}, \mathrm{Fc}\right)$. The use of poly-substituted arenes or ferrocenes has enabled preparation of the complexes 1,4$\mathrm{C}_{6} \mathrm{H}_{3}\left\{\mathrm{C} \equiv \mathrm{C}-\mu_{3}-\mathrm{C}\left[\mathrm{Co}_{3}(\mu-\mathrm{dppm})(\mathrm{CO})_{7}\right\}_{2} \mathrm{X}-5(\mathrm{X}=\mathrm{H}, \mathrm{Br}), 1,3,5-\mathrm{C}_{6} \mathrm{H}_{3}\left\{\mathrm{C} \equiv \mathrm{C}-\mu_{3}-\mathrm{C}\left[\mathrm{Co}_{3}(\mu-\right.\right.\right.$ dppm $\left.)(\mathrm{CO})_{7}\right\}_{3}$ and $1,1^{\prime}-\mathrm{Fc}^{\prime}\left\{\left\{\mathrm{C} \equiv \mathrm{C}-\mu_{3}-\mathrm{C}\left[\mathrm{Co}_{3}(\mu-\mathrm{dppm})(\mathrm{CO})_{7}\right\}_{2}\left(\mathrm{Fc}^{\prime}=\mathrm{Fe}\left(\eta-\mathrm{C}_{5} \mathrm{H}_{4}-\right)_{2}\right]\right.\right.$. The $\mathrm{X}$-ray determined molecular structures of twelve of the complexes are reported. 


\section{Introduction}

Current interest in metal complexes containing metal-ligand centres end-capping carbon chains derives in part from their potential as models for molecular wires or as components of molecular-scale electronic devices and memories and for their non-linear optical properties. ${ }^{1}$ Synthetic methods have used synthons derived from alkynes or polyynes, in which the substituent-free carbon chains are already present. As a result, the majority of known compounds have even-numbered carbon chains. ${ }^{2}$

The formation of odd-numbered chains is dependent on methods which have an oddnumbered carbon precursor, either being converted to a $\mathrm{C}_{\mathrm{n}}$ chain by subsequent reactions, or as a component in an appropriate coupling reaction. Notable examples include $\left[\left\{\mathrm{Tp}^{*}(\mathrm{OC})_{2} \mathrm{M}\right\}=\mathrm{C}=\mathrm{C}=\mathrm{C}=\left\{\mathrm{M}(\mathrm{CO})_{2} \mathrm{Tp}^{*}\right\}\right]^{2+}$ and $\left\{\mathrm{Tp} *(\mathrm{OC})_{2} \mathrm{M}\right\} \equiv \mathrm{CC} \equiv \mathrm{C}\left\{\mathrm{M}^{\prime}(\mathrm{O})_{2} \mathrm{Tp}^{*}\right\}(\mathrm{M}$, $\left.\mathrm{M}^{\prime}=\mathrm{Mo}, \mathrm{W}\right),^{5}\left[\left\{\mathrm{Cp}^{\prime}(\mathrm{OC})_{2} \mathrm{Mn}\right\} \mathrm{CCC}\left\{\operatorname{Re}(\mathrm{NO})\left(\mathrm{PPh}_{3}\right) \mathrm{Cp}^{*}\right\}\right]^{+6}$ and $\left\{\left(\mathrm{Bu}^{\mathrm{t} O}\right)_{3} \mathrm{~W}\right\} \equiv \mathrm{CC} \equiv \mathrm{C}\left\{\mathrm{Re}(\mathrm{NO})\left(\mathrm{PPh}_{3}\right) \mathrm{Cp}^{*}\right\}{ }^{7}$ We and others have considered an approach to this type of complex using a precursor in which a carbyne ligand, $\equiv \mathrm{CR}$, is attached to a metal centre. Recent examples have used the Group 6 complexes $M(\equiv C R)(C O)_{2} T p '(R=$ halogen, $\left.\mathrm{SiMe}_{3} ; \mathrm{M}=\mathrm{Mo}, \mathrm{W} ; \mathrm{Tp}{ }^{\prime}=\mathrm{BH}(\mathrm{pz})_{3}(\mathrm{Tp}), \mathrm{BH}(\mathrm{dmpz})_{3}\left(\mathrm{Tp}^{*}\right)\right]^{8}$ or cluster-bonded halocarbynes, such as $\mathrm{M}_{3}(\mu-\mathrm{CR})(\mathrm{CO})_{9}\left[\mathrm{M}_{3}=\mathrm{Ru}_{3}(\mu-\mathrm{H})_{3},{ }^{9} \mathrm{Os}_{3}(\mu-\mathrm{H})_{3},{ }^{9} \mathrm{Co}_{3}{ }^{10}\right]$.

The $\mathrm{CCo}_{3}$ trigonal cluster has been known since the late1950s ${ }^{11}$ and its extensive chemistry has been reviewed on several occasions. ${ }^{12-17}$ Attachment to unsaturated groups such as alkynes and diynes was first described in $1970 .{ }^{18-20}$ Common routes to the formation of the carbyne-C(sp) bond include the Cadiot-Chodkiewicz and Sonogashira and related reactions. ${ }^{19}$ In some instances, appropriate Grignard or Lewis-acid $\left(\mathrm{AlCl}_{3}\right)$ induced coupling reactions between alkynes and $\mathrm{Co}_{3}(\mu-\mathrm{CBr})(\mathrm{CO})_{9}$ have been employed. ${ }^{10 \mathrm{c}}$ It was early noted that with metal complexes the amine solvent commonly used often resulted in competing degradation of the cluster and conversion to other unwanted cluster products. ${ }^{19}$

Some time ago, we described a modification of this reaction whereby reactions of $\mathrm{Co}_{3}\left(\mu_{3}-\right.$ $\mathrm{CBr})(\mu$-dppm $)(\mathrm{CO})_{7}(\mathbf{1})$, chosen because the presence of the edge-bridging diphosphine 
ligand prevents break-up of the $\mathrm{CCO}_{3}$ cluster, with phosphine-gold(I) alkynyls resulted in elimination of $\mathrm{AuBr}\left(\mathrm{PR}_{3}\right)$ and formation of the $\mathrm{C}-\mathrm{C}$ bonded product in high yields. ${ }^{21} \mathrm{We}$ had reasoned that the presence of the dppm ligand, bridging one of the Co-Co edges, would serve to prevent cluster degradation, while the mild conditions of the reaction, in which no base is required, would prevent the formation of unwanted by-products. While our first accounts concentrated on the formation of carbon chains end-capped by the $\mathrm{Co}_{3}$ cluster and a second metal-containing group, ${ }^{10}$ we have also extended these reactions to the synthesis of a range of $\mathrm{Co}_{3}$ clusters containing more conventional groups as described below.

\section{Results and Discussion}

Reactions of $\mathrm{Co}_{3}\left(\mu_{3}-\mathrm{CBr}\right)(\mu-\mathrm{dppm})(\mathrm{CO})_{7}(\mathbf{1})^{22}$ with phosphine-gold(I) alkynyls proceed readily in solvents such as thf under mild conditions (r.t., hours). Conventional work-up involving chromatography on silica gel affords the alkynyl-tricobaltcarbon clusters in high yield as dark coloured crystals. To exemplify this reaction, we have used $\mathrm{Au}(\mathrm{C} \equiv \mathrm{CR})\left(\mathrm{PPh}_{3}\right)$, or occasionally the $\mathrm{P}(\mathrm{tol})_{3}$ analogue to improve solubility, which has allowed the complexes $\mathrm{Co}_{3}\left(\mu_{3}-\mathrm{CC} \equiv \mathrm{CR}\right)(\mu$-dppm $)(\mathrm{CO})_{7}$ to be obtained $\left[\mathrm{R}=\mathrm{Bu}^{\mathrm{t}}(\mathbf{2}, 47 \%)\right.$, $\left.\mathrm{Ph}(\mathbf{3}, 91 \%), \mathrm{SiMe}_{3}(\mathbf{4}, 86 \%), \mathrm{Fc}(\mathbf{5}, 91 \%)\right]$. The co-product $\mathrm{AuBr}\left(\mathrm{PR}_{3}^{\prime}\right)\left(\mathrm{R}^{\prime}=\mathrm{Ph}, \mathrm{tol}\right)$ can be easily recovered and recycled. The IR spectra of these complexes contain weak $v(\mathrm{C} \equiv \mathrm{C})$ bands at ca $2130 \mathrm{~cm}^{-1}$ and medium to strong $v(\mathrm{CO})$ absorptions between 2061 and $1966 \mathrm{~cm}^{-1}$. In addition to common signals at $\delta 3.44$ and 4.49 and between $\delta 6.5$ and 8.0 arising from the dppm ligand, the ${ }^{1} \mathrm{H}$ NMR spectrum contain other resonances characteristic of the $\mathrm{R}$ groups present. Limited solubility restricted the availability of ${ }^{13} \mathrm{C}$ NMR spectra, but in 2, signals at $\delta 101.14$ and 121.95 can be assigned to two carbons of the $\mathrm{C}_{3}$ moiety. That of the carbyne carbon, attached to three cobalt atoms, is broadened by interaction with the ${ }^{59} \mathrm{Co}$ quadrupole and is not resolved in all spectra. ${ }^{23,24}$ The ${ }^{31} \mathrm{P}$ NMR spectra contain a single resonance at $\delta$ ca 35 . The formulations of these complexes are confirmed by elemental analyses and by their electrospray mass spectra (ES MS), which usually contain molecular ions or appropriate adduct ions. As described further below, the molecular structures of twelve of the complexes have been determined by single-crystal X-ray diffraction studies. 
The elimination reaction also proceeds between phosphine-gold(I) derivatives of the alkynyl-tricobalt cluster and appropriate $\mathrm{C}\left(\mathrm{sp}_{\mathrm{p}} \mathrm{sp}^{2}\right)$-I bonds. Thus, the reaction between $\mathrm{Co}_{3}\left\{\mu_{3}-\mathrm{CC} \equiv \mathrm{CAu}\left(\mathrm{PPh}_{3}\right)\right\}(\mu$-dppm $)(\mathrm{CO})_{7}(\mathbf{6})$, itself prepared from the $\mathrm{SiMe}_{3}$ derivative 4 and $\mathrm{AuCl}\left(\mathrm{PPh}_{3}\right)$ in the presence of sodium methoxide, and 1,4- $\mathrm{I}_{2} \mathrm{C}_{6} \mathrm{H}_{4}$ afforded two complexes which were characterised as $\mathrm{Co}_{3}\left(\mu_{3}-\mathrm{CC} \equiv \mathrm{CC}_{6} \mathrm{H}_{4} \mathrm{I}-4\right)(\mu-\mathrm{dppm})(\mathrm{CO})_{7}(7)$ which is green, and orange-brown $\left\{\mathrm{Co}_{3}(\mu-\mathrm{dppm})(\mathrm{CO})_{7}\right\}_{2}\left(\mu_{3}: \mu_{3}-\mathrm{CC} \equiv \mathrm{CC}_{6} \mathrm{H}_{4} \mathrm{C} \equiv \mathrm{CC}\right)(\mathbf{8})$. Similarly, the reaction between $\mathrm{Au}\left(\mathrm{C} \equiv \mathrm{CC}_{6} \mathrm{H}_{4} \mathrm{C} \equiv \mathrm{CPh}\right)\left(\mathrm{PPh}_{3}\right)$ and 1 afforded $\mathrm{Co}_{3}\left(\mu_{3}-\right.$ $\left.\mathrm{CC} \equiv \mathrm{CC}_{6} \mathrm{H}_{4} \mathrm{C} \equiv \mathrm{CPh}\right)(\mu-\mathrm{dppm})(\mathrm{CO})_{7}(9)$. These complexes were readily separated by preparative t.l.c. and identified by elemental analysis and their ES MS. The other spectroscopic properties were similar to those found for the related phenyl complex. ${ }^{22 a}$

Extension of the reaction to 1,3,5- $\left\{\left(\mathrm{Ph}_{3}\right) \mathrm{AuC} \equiv \mathrm{C}\right\}_{3} \mathrm{C}_{6} \mathrm{H}_{3}$ enabled preparation of the triscluster complex 1,3,5-\{(OC) $\left.)_{7}(\mu-\mathrm{dppm}) \mathrm{Co}_{3}\left(\mu_{3}-\mathrm{CC} \equiv \mathrm{C}\right)\right\}_{3} \mathrm{C}_{6} \mathrm{H}_{3}(\mathbf{1 0})$ in $50 \%$ yield. This compound has a similar $\mathrm{n}(\mathrm{CO})$ spectrum to the complexes described above, while the ${ }^{13} \mathrm{C}$ NMR spectrum contains resonances at $\delta 108.92$ and 112.78 from two of the $\mathrm{C}_{3}$ chain carbons. Further characterisation results from the ES MS which contains a molecular ionat $\mathrm{m} / \mathrm{z} 2454$, and by an X-ray structural determination (see below). On one occasion, we isolated and crystallographically characterised the bis-cluster $1,3-\left\{(\mathrm{OC})_{7}(\mu-\right.$ dppm) $\left.\mathrm{Co}_{3}\left(\mu_{3}-\mathrm{CC} \equiv \mathrm{C}\right)\right\}_{2} \mathrm{C}_{6} \mathrm{H}_{3} \mathrm{Br}-5$ (11) from an analogous reaction in which the bromoaryldiyne 1,3- $\left\{\left(\mathrm{Ph}_{3}\right) \mathrm{AuC} \equiv \mathrm{C}\right\}_{3} \mathrm{C}_{6} \mathrm{H}_{3} \mathrm{Br}-5$ was inadvertently used. Its spectroscopic properties were similar to those found for $\mathbf{9}$, with the exception of the negative ion ES MS, which a molecular anion was found at $m / z 1741$.

In addition to the binuclear complex 8 , we have prepared $1,1^{\prime}-\left\{\mathrm{Co}_{3}(\mu-\right.$ dppm $\left.)(\mathrm{CO})_{7} \mathrm{C} \equiv \mathrm{CC}\right\}_{2} \mathrm{Fc}^{\prime}\left[\mathbf{1 2}, \mathrm{Fc}^{\prime}=\mathrm{Fe}\left(\eta-\mathrm{C}_{5} \mathrm{H}_{4}-\right)_{2}\right]$ in $96 \%$ yield from the related reaction between $1,1^{\prime}-\mathrm{Fc}^{\prime}\left\{\mathrm{Au}\left[\mathrm{P}(\mathrm{tol})_{3}\right]\right\}_{2}$ and $\mathrm{Co}_{3}\left(\mu_{3}-\mathrm{CBr}\right)(\mu$-dppm $)(\mathrm{CO})_{7}$. This dark red complex has an IR $v(\mathrm{CO})$ spectrum similar to those of the other complexes described above, together with $v(\mathrm{CC})$ at $2122 \mathrm{~cm}^{-1}$. The ${ }^{1} \mathrm{H}$ NMR spectrum has two $4 \mathrm{H}$ multiplets at $\delta$ 
4.40 and 4.53 assigned to the $\mathrm{C}_{5} \mathrm{H}_{4}$ protons of the ferrocene nucleus, while the ES MS of a solution containing $\mathrm{NaOMe}$ contains $[\mathrm{M}+\mathrm{Na}]^{+}$at $m / z 1793$.

Related complexes containing $\mathrm{C}_{5}$ chains, such as $\mathrm{Co}_{3}\left(\mu_{3}-\mathrm{CC} \equiv \mathrm{CC} \equiv \mathrm{CR}\right)(\mu-\mathrm{dppm})(\mathrm{CO})_{7}(\mathrm{R}$ $\left.=\mathrm{SiMe}_{3}, \mathrm{Au}\left(\mathrm{PPh}_{3}\right), \mathrm{Fc}\right)$ have been described earlier. ${ }^{10}$ Extension to systems containing $\mathrm{C}_{7}$ chains was easily achieved in reactions between $\mathrm{Co}_{3}\left\{\mu_{3}-\mathrm{CC} \equiv \mathrm{CC} \equiv \mathrm{CAu}\left(\mathrm{PPh}_{3}\right)(\mu\right.$ dppm $)(\mathrm{CO})_{7}^{10}$ and IC $\equiv \mathrm{CSiMe}_{3}{ }^{25}$ or $\mathrm{IC} \equiv \mathrm{CFc}^{26}$ which gave $\mathrm{Co}_{3}\left\{\mu_{3}-\mathrm{C}(\mathrm{C} \equiv \mathrm{C})_{3} \mathrm{R}\right\}(\mu-$ $\mathrm{dppm})(\mathrm{CO})_{7}\left[\mathrm{R}=\mathrm{SiMe}_{3}(\mathbf{1 3}, 54 \%), \mathrm{Fc}(\mathbf{1 4}, 87 \%)\right]$ and the further conversion of 13 by treatment with $\mathrm{NaOMe}$ and $\mathrm{AuCl}\left(\mathrm{PPh}_{3}\right)$ gave $\mathrm{Co}_{3}\left\{\mu_{3}-\mathrm{C}(\mathrm{C} \equiv \mathrm{C})_{3} \mathrm{Au}\left(\mathrm{PPh}_{3}\right\}(\mu-\mathrm{dppm})(\mathrm{CO})_{7}\right.$ (15) in $75 \%$ yield. The complex $\mathrm{Co}_{3}\left\{\mu_{3}-\mathrm{CC} \equiv \mathrm{CC} \equiv \mathrm{CAu}\left(\mathrm{PPh}_{3}\right)\right\}\left(\mu\right.$-dppm) $(\mathrm{CO})_{7}$ has been converted to $\mathrm{Co}_{3}\left(\mu_{3}-\mathrm{C}(\mathrm{C} \equiv \mathrm{C})_{3} \mathrm{Ph}\right\}(\mu-\mathrm{dppm})(\mathrm{CO})_{7}(\mathbf{1 6})$ in $60 \%$ yield by sequential reactions with iodine and $\mathrm{Au}(\mathrm{C} \equiv \mathrm{CPh})\left(\mathrm{PPh}_{3}\right)$, without isolation of the presumed intermediate iododiynyl complex $\mathrm{Co}_{3}\left(\mu_{3}-\mathrm{CC} \equiv \mathrm{CC} \equiv \mathrm{CI}\right)(\mu-\mathrm{dppm})(\mathrm{CO})_{7}$.

Complexes 13-16 were initially characterised by elemental microanalyses and from their ES MS. Other spectroscopic properties were also in agreement with the proposed structures. These complexes have similar IR spectra to their shorter chain analogues, although for $\mathbf{1 4}$ and 16, two $v(\mathrm{C} \equiv \mathrm{C})$ absorptions are found. In the NMR spectra of $\mathbf{1 3}$, the $\mathrm{SiMe}_{3}$ group gives rise to a singlet at $\delta_{\mathrm{H}} 0.26$, while for $\mathbf{1 4}$, resonances at $\delta_{\mathrm{H}} 4.28,4.30$ and 4.56 and $\delta_{c} 70.35,69.76$ and 72.35 arise from the $\mathrm{Cp}$ and $\mathrm{C}_{5} \mathrm{H}_{4}$ rings of the $\mathrm{Fc}$ group. We assign seven resonances found between $\delta 63.38$ and 99.03 in the ${ }^{13} \mathrm{C}$ NMR spectrum to six of the $\mathrm{C}_{7}$ carbons and the ipso carbons of the Ph groups. In the ${ }^{13} \mathrm{C}$ NMR spectra of 14 and 15, resonances between $\delta 57$ and 99 are assigned to five of the seven chain carbons, the $\mathrm{Co}_{3} \mathrm{C}$ atom again not being observed.

\section{Structural studies}

The molecular structures of 12 of the complexes described above have been determined by single-crystal X-ray diffraction studies. Figs. 1-12 contain plots of single molecules of each complex, that of $\mathbf{5}$ showing the two different conformers found in the unit cell. All contain as a common structural feature the $\mathrm{Co}_{3}\left(\mu_{3}-\mathrm{CC} \equiv \mathrm{C}-\right)(\mu-\mathrm{dppm})(\mathrm{CO})_{7}$ fragment (the molecule of $\mathbf{1 2}$ is centrosymmetric), as has been found in several other related 
complexes described by us ${ }^{10,27}$ and others ${ }^{28-31}$ on previous occasions. Atom $\mathrm{C}(1)$ is attached to all three metal atoms of the triangular $\mathrm{Co}_{3}$ cluster, of which one edge $[\mathrm{Co}(1)-\mathrm{Co}(2)]$ is bridged by the dppm ligand. In all cases except $\mathbf{2}$ and $\mathbf{4}$ (which are isomorphous), the methylene bridge of the dppm ligand lies 'endo' to the pendant alkyne group, whereas it is 'exo' in the two exceptions. Nevertheless, the ranges encompassed by the various bond distances and angles extend over many standard deviations (see Table 1), although it is not evident that any particular structural or electronic feature can account for the differences.

In some instances, the dppm-bridged $\mathrm{Co}(1)-\mathrm{Co}(2)$ bond is significantly different from the other two Co-Co separations, although when averaged over the present examples, both distances are identical (2.481 $\mathrm{A}$ ), with ranges for $\mathrm{Co}(1)-\mathrm{Co}(2)$ of between 2.4624-2.5144 $\AA$ and for $\mathrm{Co}(1,2)-\mathrm{Co}(3)$ of 2.4651-2.5085 $\AA$. The Co-P bonds to the dppm ligand average $2.197 \AA$ (range 2.177-2.2154 $\AA$ ). Only in the interactions of the $\mathrm{Co}_{3}$ cluster with the capping $\mathrm{C}(1)$ atom are differences found, with $\mathrm{Co}(1,2)-\mathrm{C}(1)$ averaging $1.905 \AA$ (range


the increased electron density at $\operatorname{Co}(1,2)$ and increased back-bonding into the corresponding Co-C Mos. ${ }^{32}$

The carbon chains show the expected alternation of C-C bond lengths, with $\mathrm{C}(1)-\mathrm{C}(2)$ ranging between 1.381-1.422 $\AA$ (av. $1.399 \AA$ ) and $\mathrm{C}(2)-\mathrm{C}(3)$ being shorter at $1.213 \AA$ (av.), range 1.201-1.230 $\AA$, consistent with its being a $\mathrm{C} \equiv \mathrm{C}$ triple bond. As expected, angles at $\mathrm{C}(1,2)$ are close to linear, averaging $177.2^{\circ}$ (range $174.3-179.8^{\circ}$ ) and 174.7 (range (167.9-179.3 ${ }^{\circ}$ ), respectively. In triyne complexes 11 and 12, separations further along the $\mathrm{C}_{7}$ chain are consistent with this formulation, with $\mathrm{C}(4)-\mathrm{C}(5)$ and $\mathrm{C}(6)-\mathrm{C}(7)$ triple bonds $[1.217,1.203(4) \AA$ in 11, 1.226, 1.209(7) in 12] and C(3)-C(4) and C(5)-C(6) single bonds $[1.355,1.366(4) \AA$ in $\mathbf{1 1}, 1.343,1.358(7)$ in 12]. In these two examples, a trend for shorter $\mathrm{C} \equiv \mathrm{C}$ triple bonds further along the $\mathrm{C}_{\mathrm{n}}$ chain from the $\mathrm{Co}_{3}$ cluster is evident, while the reverse occurs for the $\mathrm{C}-\mathrm{C}$ single bonds. The conformations of these two $\mathrm{C}_{7}$ chains can be described as a continuous bend, with total bending at the carbon atoms $\mathrm{C}(2-7)$, $\Sigma$, being 19.4 (for 11) and $23.6^{\circ}$ (for 12). Others have commented previously about the facile bending of $\mathrm{C}(\mathrm{sp})$ chains, the most probable explanation being 
found in intermolecular interactions within the cell and the facile bending modes of $\mathrm{C}(\mathrm{sp})$ chains. $^{33}$

Other features of the structures are consistent with the groups found at the other end of the carbon chain, with $\mathrm{C}(3)-\mathrm{X}$ distances $[\mathrm{X}=\mathrm{Au}$ 1.983(4), C(301) of aromatic groups 1.405-1.440(5), Si 1.845(6) Å]. Despite pseudo-symmetry in their disposition in the cell, the two independent molecules of $\mathbf{5}$ have different conformations of the Fc group, with the Fe-mid-ring vectors being approximately parallel and perpendicular to the $\mathrm{Co}(1)$ $\mathrm{Co}(2)$ vector, no doubt imposed by packing requirements of the $\mathrm{Ph}$ and $\mathrm{Fc}$ groups therein.

\section{Experimental}

General. All reactions were carried out under dry nitrogen, although normally no special precautions to exclude air were taken during subsequent work-up. Common solvents were dried, distilled under argon and degassed before use. Separations were carried out by preparative thin-layer chromatography on glass plates $\left(20 \times 20 \mathrm{~cm}^{2}\right)$ coated with silica gel (Merck, $0.5 \mathrm{~mm}$ thick).

Instruments. IR spectra were obtained on a Bruker IFS28 FT-IR spectrometer. Spectra in $\mathrm{CH}_{2} \mathrm{Cl}_{2}$ were obtained using a $0.5 \mathrm{~mm}$ path-length solution cell with $\mathrm{NaCl}$ windows. Nujol mull spectra were obtained from samples mounted between $\mathrm{NaCl}$ discs. NMR spectra were recorded on a Varian 2000 instrument $\left({ }^{1} \mathrm{H}\right.$ at $300.13 \mathrm{MHz},{ }^{13} \mathrm{C}$ at 75.47 $\mathrm{MHz},{ }^{31} \mathrm{P}$ at $121.503 \mathrm{MHz}$ ). Unless otherwise stated, samples were dissolved in $\mathrm{CDCl}_{3}$ contained in $5 \mathrm{~mm}$ sample tubes. Chemical shifts are given in ppm relative to internal tetramethylsilane for ${ }^{1} \mathrm{H}$ and ${ }^{13} \mathrm{C}$ NMR spectra and external $\mathrm{H}_{3} \mathrm{PO}$ for ${ }^{31} \mathrm{P}$ NMR spectra. Electrospray mass spectra (ES MS) were obtained from samples dissolved in $\mathrm{MeOH}$ unless otherwise indicated. Solutions were injected into a Varian Platform II spectrometer via a $10 \mathrm{ml}$ injection loop. Nitrogen was used as the drying and nebulising gas. Chemical aids to ionisation were used..$^{34}$ Elemental analyses were by CMAS, Belmont, Vic., Australia. 
Reagents. $\mathrm{Co}_{3}\left(\mu_{3}-\mathrm{CBr}\right)(\mu-\mathrm{dppm})(\mathrm{CO})_{7}{ }^{27} \mathrm{AuCl}\left(\mathrm{PR}_{3}\right)(\mathrm{R}=\mathrm{Ph} ;$ tol made similarly $),{ }^{35}$ and $\mathrm{Au}\left(\mathrm{C} \equiv \mathrm{CR}^{\prime}\right)\left(\mathrm{PR}_{3}\right)\left(\mathrm{R}^{\prime}=\mathrm{Bu}^{\mathrm{t}}, \mathrm{Ph}, \mathrm{SiMe}_{3}, \mathrm{Fc}\right)$ and $\left\{\mathrm{Au}\left(\mathrm{PR}_{3}\right)\right\}_{2}\left(\mu-\mathrm{C} \equiv \mathrm{CC}_{6} \mathrm{H}_{4} \mathrm{C} \equiv \mathrm{C}\right)$ were obtained as previously described. ${ }^{36,37}$

Preparation of $\mathrm{Au}\left(\mathrm{C} \equiv \mathrm{CC}_{6} \mathrm{H}_{4} \mathrm{C} \equiv \mathrm{CPh}\right)\left(\mathrm{PPh}_{3}\right)$

Sodium (30 mg) was added to a solution of $\mathrm{AuCl}\left(\mathrm{PPh}_{3}\right)(91 \mathrm{mg}, 0.184 \mathrm{mmol})$ in $\mathrm{MeOH}$ (28 ml). After hydrogen evolution had ceased, a solution of $\mathrm{HC} \equiv \mathrm{CC}_{6} \mathrm{H}_{4} \mathrm{C} \equiv \mathrm{CPh}(37 \mathrm{mg}$, $0.183 \mathrm{mmol})$ in $\mathrm{MeOH}(2 \mathrm{ml})$ was added dropwise. After stirring at r.t. for $12 \mathrm{~h}$, solvent was removed and the residue was extracted into benzene. Concentration of the extract to $3 \mathrm{ml}$ and diffusion of hexanes $(3 \mathrm{ml})$ into the concentrated solution gave light yellow microcrystalline $\mathrm{Au}\left(\mathrm{C} \equiv \mathrm{CC}_{6} \mathrm{H}_{4} \mathrm{C} \equiv \mathrm{CPh}\right)\left(\mathrm{PPh}_{3}\right)(99.5 \mathrm{mg}, 83 \%)$, which was washed with hexane and dried. Anal. Found: C, 61.62; H, 3.57. Calcd $\left(\mathrm{C}_{34} \mathrm{H}_{24} \mathrm{AuP}\right): \mathrm{C}, 61.82 ; \mathrm{H}$, 3.64; $M$, 660. IR $\left(\mathrm{CH}_{2} \mathrm{Cl}_{2}\right): v(\mathrm{C} \equiv \mathrm{C}) 2114 \mathrm{w} \mathrm{cm}^{-1} .{ }^{1} \mathrm{H} \mathrm{NMR}: \delta 7.27-7.60(\mathrm{~m}, 24 \mathrm{H}, \mathrm{Ph}+$ $\left.\mathrm{C}_{6} \mathrm{H}_{4}\right) .{ }^{31} \mathrm{P}$ NMR: $\delta$ 42.58s. ES-MS: (positive ion, $\left.\mathrm{MeOH}+\mathrm{NaOMe}, m / z\right): 683,[\mathrm{M}+$ $\mathrm{Na}]^{+}$.

Preparation of $1,3,5-\left\{\left(\mathrm{Ph}_{3} \mathrm{P}\right) \mathrm{AuC} \equiv \mathrm{C}\right\}_{3} \mathrm{C}_{6} \mathrm{H}_{3}$

A modified literature method ${ }^{38}$ was used. $\mathrm{NaOMe}$ (excess) in $\mathrm{MeOH}(4 \mathrm{ml})$ was added to a solution of $\mathrm{AuCl}\left(\mathrm{PPh}_{3}\right)(202.7 \mathrm{mg}, 0.41 \mathrm{mmol})$ and 1,3,5-( $\left.\mathrm{Me}_{3} \mathrm{SiC} \equiv \mathrm{C}\right)_{3} \mathrm{C}_{6} \mathrm{H}_{3}(50 \mathrm{mg}$, $0.137 \mathrm{mmol})$ in thf $/ \mathrm{MeOH}(30 \mathrm{ml} / 8 \mathrm{ml})$ at $0^{\circ} \mathrm{C}$ (ice-bath) and the mixture was allowed to warm to r.t. After stirring overnight, a white precipitate had separated from the pale yellow solution. Solvent was removed and the solid remaining was transferred to a sinter with $\mathrm{MeOH}(5 \mathrm{ml})$ and washed with more $\mathrm{MeOH}$ and hexane, and dried in air to give 1,3,5- $\left\{\left(\mathrm{Ph}_{3} \mathrm{P}\right) \mathrm{AuC} \equiv \mathrm{C}\right\}_{3} \mathrm{C}_{6} \mathrm{H}_{3}(181 \mathrm{mg}, 87 \%)$ as a pale yellow solid. ${ }^{1} \mathrm{H}$ NMR: $\delta$ 7.47$7.59(\mathrm{~m}, \mathrm{Ph}) .{ }^{13} \mathrm{C}$ NMR: $\delta 103.62(\mathrm{C} \equiv \mathrm{C}), 124.35\left(\mathrm{~s}, \mathrm{C}_{\mathrm{ipso}}\right.$ of $\left.\mathrm{C}_{6} \mathrm{H}_{3}\right), 18.89-131.44(\mathrm{~m}, \mathrm{Ph})$, 134.20, $134.36\left(\mathrm{C}_{6} \mathrm{H}_{3}\right) .{ }^{31} \mathrm{P}$ NMR: $\delta 49.33\left(\mathrm{~s}, \mathrm{PPh}_{3}\right)$.

Preparation of carbon-tricobalt complexes

$\mathrm{Co}_{3}\left\{\mu_{3}-C(C \equiv C)_{n} R\right\}(\mu-d p p m)(C O)_{7}, n=1$

(i) $\mathrm{R}=\mathrm{Bu}^{\mathrm{t}}(\mathbf{2})$ 
A mixture of $\mathrm{Au}\left(\mathrm{C} \equiv \mathrm{CBu}^{\mathrm{t}}\right)(64 \mathrm{mg}, 0.12 \mathrm{mmol}), \mathrm{Co}_{3}\left(\mu_{3}-\mathrm{CBr}\right)(\mu-\mathrm{dppm})(\mathrm{CO})_{7}(100 \mathrm{mg}$, $0.12 \mathrm{mmol}), \mathrm{Pd}\left(\mathrm{PPh}_{3}\right)_{4}(6.2 \mathrm{mg}, 0.006 \mathrm{mmol})$ and $\mathrm{CuI}(1 \mathrm{mg}, 0.005 \mathrm{mmol})$ in thf $(7 \mathrm{ml})$ was stirred at r.t. for $2 \mathrm{~h}$. After removal of solvent, the residue was extracted with $\mathrm{CH}_{2} \mathrm{Cl}_{2}$ and separated by preparative t.l.c. (hexane-acetone 5/1). The major brown band $\left(R_{\mathrm{f}} 0.41\right)$ contaned $\mathrm{Co}_{3}\left(\mu_{3}-\mathrm{CC} \equiv \mathrm{CBu}^{t}\right)(\mu-\mathrm{dppm})(\mathrm{CO})_{7}(2)(47 \mathrm{mg}, 47 \%)$ which was isolated as dark brown crystals $\left(\mathrm{CH}_{2} \mathrm{Cl}_{2} / \mathrm{MeOH}\right)$. Anal. Found: C, 55.09; H, 3.42. Calcd $\left(\mathrm{C}_{39} \mathrm{H}_{31} \mathrm{Co}_{3} \mathrm{O}_{7} \mathrm{P}_{2}\right): \mathrm{C}, 55.06 ; \mathrm{H}, 3.65 ; M, 850$. IR $\left(\mathrm{CH}_{2} \mathrm{Cl}_{2}, \mathrm{~cm}^{-1}\right): v(\mathrm{C} \equiv \mathrm{C}) 2131 \mathrm{vw}$; v(CO) 2057s, 2007vs, 1987 (sh), 1966 (sh); (cyclohexane): v(CO) 2061s, 2015vs, 2011vs, 1997m, 1984w, 1976m, 1960w. ' $\mathrm{H}$ NMR: $\delta 1.41$ (s, 9H, But), 3.49, $4.41(2 \mathrm{x} \mathrm{s}$, 2 x 1H, dppm), 6.50-8.50 (m, 20H, Ph). ${ }^{13} \mathrm{C}$ NMR: $\delta 30.33$ (s, Me), $30.80\left(\mathrm{~s}, \mathrm{C}^{4}\right), 39.94$ [t, J(CP) $21.8 \mathrm{~Hz}, \mathrm{PCH}_{2}$ ], $101.14\left(\mathrm{~s}, \mathrm{C}^{3}\right), 121.95$ (s, C $)$, 128.12-137.49 (m, Ph), 202.43, 209.83, 231.35 (3 x s, br, CO). ${ }^{31}$ P NMR: $\delta$ 33.8s. ES-MS (MeOH, $\left.m / z\right): 850, \mathrm{M}^{+}$.

(ii) $\mathrm{R}=\mathrm{Ph}(\mathbf{3})$

Method A: A mixture of $\mathrm{Au}(\mathrm{C} \equiv \mathrm{CPh})\left(\mathrm{PPh}_{3}\right)(66 \mathrm{mg}, 0.12 \mathrm{mmol}), \mathrm{Co}_{3}\left(\mu_{3}-\mathrm{CBr}\right)(\mu-$ $\mathrm{dppm})(\mathrm{CO})_{7}(100 \mathrm{mg}, 0.12 \mathrm{mmol}), \mathrm{Pd}\left(\mathrm{PPh}_{3}\right)_{4}(7 \mathrm{mg}, 0.006 \mathrm{mmol})$ and $\mathrm{CuI}(2 \mathrm{mg}, 0.012$ $\mathrm{mmol})$ in thf $(7 \mathrm{ml})$ was stirred at r.t. for $1 \mathrm{~h}$. After removal of solvent, the residue was taken up in $\mathrm{CH}_{2} \mathrm{Cl}_{2}$ and purified by preparative t.l.c. (acetone-hexane 3/7). The major brown-green band $\left(R_{\mathrm{f}} 0.69\right)$ contained $\mathrm{Co}_{3}\left(\mu_{3}-\mathrm{CC} \equiv \mathrm{CPh}\right)(\mu$-dppm $)(\mathrm{CO})_{7}(3)(93.2 \mathrm{mg}$, 91\%) as dark green crystals $\left(\mathrm{CH}_{2} \mathrm{Cl}_{2} / \mathrm{MeOH}\right)$. Anal. Found: C, 54.73; H, 2.75. Calcd $\left(\mathrm{C}_{41} \mathrm{H}_{27} \mathrm{Co}_{3} \mathrm{O}_{7} \mathrm{P}_{2} .0 .5 \mathrm{CH}_{2} \mathrm{Cl}_{2}\right): \mathrm{C}, 54.57 ; \mathrm{H}, 3.28 ; M, 870 . \mathrm{IR}\left(\mathrm{CH}_{2} \mathrm{Cl}_{2}, \mathrm{~cm}^{-1}\right): v(\mathrm{C} \equiv \mathrm{C})$ 2116vw; v(CO) 2058s, 2009vs, 1989 (sh), 1969 (sh), 1948 (sh). ${ }^{1}$ H NMR: $\delta 3.44,4.49$ (2 x s, 2 x 1H, dppm), $5.30\left(\mathrm{~s}, \mathrm{CH}_{2} \mathrm{Cl}_{2}\right), 7.14-7.59$ (m, 25H, Ph). ${ }^{31} \mathrm{P}$ NMR: $\delta 34.19$ [s (br), dppm]. ES-MS (positive ion, $\mathrm{MeOH}+\mathrm{NaOMe}, m / z$ ): 893, [M $+\mathrm{Na}]^{+}$; (negative ion, $\mathrm{MeOH}, m / z): 869,[\mathrm{M}-\mathrm{H}]^{+}$.

Method B: When $\operatorname{Ag}(\mathrm{C} \equiv \mathrm{CPh})\left(\mathrm{PPh}_{3}\right)$ was used under the same conditions, 3 was obtained in $55 \%$ yield.

(iii) $\quad \mathrm{R}=\mathrm{SiMe}_{3}(4)$ 
Method A: $\mathrm{Pd}\left(\mathrm{PPh}_{3}\right)_{4}(6 \mathrm{mg}, 0.005 \mathrm{mmol})$ and $\mathrm{CuI}(1 \mathrm{mg}, 0.005 \mathrm{mmol})$ were added to a solution of $\mathrm{Co}_{3}\left(\mu_{3}-\mathrm{CBr}\right)(\mu-\mathrm{dppm})(\mathrm{CO})_{7}(84.9 \mathrm{mg}, 0.1 \mathrm{mmol})$ and $\mathrm{Au}\left(\mathrm{C} \equiv \mathrm{CSiMe}_{3}\right)\left(\mathrm{PPh}_{3}\right)$ $(55.6 \mathrm{mg}, 0.1 \mathrm{mmol})$ in thf $(5 \mathrm{ml})$ and the mixture was stirred at r.t. for $2 \mathrm{~h}$. After removal of solvent under reduced pressure, the residue was dissolved in acetone-hexane (3/7) and run through a silioca gel column using the same solvent mixture as eluent. A major brown-green fraction was collected and after evaporation gave $\mathrm{Co}_{3}\left(\mu_{3}\right.$ $\left.\mathrm{CC} \equiv \mathrm{CSiMe}_{3}\right)(\mu-\mathrm{dppm})(\mathrm{CO})_{7}(4)(75 \mathrm{mg}, 86 \%)$ as dark green crystals (hexane). Anal. Calcd $\left(\mathrm{C}_{38} \mathrm{H}_{31} \mathrm{Co}_{3} \mathrm{O}_{7} \mathrm{P}_{2} \mathrm{Si}\right): \mathrm{C}, 52.68 ; \mathrm{H}, 3.61 ; M, 866$. Found: C, 52.64; H, 3.62. IR $\left(\mathrm{CH}_{2} \mathrm{Cl}_{2}, \mathrm{~cm}^{-1}\right): v(\mathrm{C} \equiv \mathrm{C}) 2138 \mathrm{vw} ; \mathrm{v}(\mathrm{CO}) 2065 \mathrm{~s}, 2048 \mathrm{~s}, 2010 \mathrm{vs}, 1990$ (sh). ${ }^{1} \mathrm{H}$ NMR: $\delta$ 0.32 (s, 9H, $\left.\mathrm{SiMe}_{3}\right), 3.49,4.54\left(2 \times \mathrm{m}, 2\right.$ x 1H, $\left.\mathrm{CH}_{2}\right), 7.13-7.58$ (m, 20H, Ph). ${ }^{13} \mathrm{C} \mathrm{NMR:}$ $\delta 0.10$ (s, $\mathrm{SiMe}_{3}$ ), 39.52 [t, J(CP) $\left.25.4 \mathrm{~Hz}, \mathrm{dppm}\right], 116.70,126.19$ (2 x s, carbon chain), 1228.22-137.28 (m, Ph), 202.13, 210.08, 225.14 [s (br), CO]. ${ }^{31} \mathrm{P}$ NMR: $\delta 33.32$ [s (br), dppm]. ES-MS (positive ion, $\mathrm{MeOH}+\mathrm{NaOMe}, m / z)$ ): 889, $[\mathrm{M}+\mathrm{Na}]^{+}$; (negative ion, $\mathrm{MeOH}+\mathrm{NaOMe}, m / z), 865,[\mathrm{M}-\mathrm{H}]$.

Method B: A solution of $\mathrm{Co}_{3}\left(\mu_{3}-\mathrm{CBr}\right)(\mu-\mathrm{dppm})(\mathrm{CO})_{7}(200 \mathrm{mg}, 0.24 \mathrm{mmol})$ and $\mathrm{HC} \equiv \mathrm{CSiMe}_{3}(48 \mathrm{mg}, 0.5 \mathrm{mmol})$ in thf $(10 \mathrm{ml})$ was treated with $\mathrm{CuI}(2 \mathrm{mg}, 0.012 \mathrm{mmol})$ and $\mathrm{Pd}\left(\mathrm{PPh}_{3}\right)_{4}(14 \mathrm{mg}, 0.012 \mathrm{mmol})$, followed by addition of dbu (several drops). After stirring at r.t. for $2 \mathrm{~h}$, work-up as above gave $\mathrm{Co}_{3}\left(\mu_{3}-\mathrm{CC} \equiv \mathrm{CSiMe}_{3}\right)(\mu$-dppm $)(\mathrm{CO})_{7}(4)(157$ $\mathrm{mg}, 75 \%)$. A minor product formed on some occasions was identified as $\left\{\mathrm{Co}_{3}(\mu-\right.$ $\left.\mathrm{dppm})(\mathrm{CO})_{7}\right\}_{2}\left(\mu_{3}: \mu_{3}-\mathrm{C}_{6}\right) .^{10 \mathrm{a}}$

(iv) $\quad \mathrm{R}=\mathrm{Fc}(\mathbf{5})$

Thf $(10 \mathrm{ml})$ was added to a solid mixture of $\mathrm{Au}(\mathrm{C} \equiv \mathrm{CFc})\left(\mathrm{PPh}_{3}\right)(100 \mathrm{mg}, 0.15 \mathrm{mmol})$, $\mathrm{Co}_{3}\left(\mu_{3}-\mathrm{CBr}\right)(\mu-\mathrm{dppm})(\mathrm{CO})_{7}(127 \mathrm{mg}, 0.15 \mathrm{mmol}), \mathrm{Pd}\left(\mathrm{PPh}_{3}\right)_{4}(17 \mathrm{mg}, 0.015 \mathrm{mmol})$ and $\mathrm{CuI}(3 \mathrm{mg}, 0.015 \mathrm{mmol})$ and the reaction was stirred at r.t. for $1 \mathrm{~h}$. , after which spot t.l.c. showed the absence of starting materials. After evaporation of thf, the residue was extracted with $\mathrm{CH}_{2} \mathrm{Cl}_{2}$ and purified by preparative t.l.c. (acetone-hexane 1/4). One brown band developed $\left(R_{\mathrm{f}} 0.43\right)$ and contained $\mathrm{Co}_{3}\left(\mu_{3}-\mathrm{CC} \equiv \mathrm{CFc}\right)(\mu-\mathrm{dppm})(\mathrm{CO})_{7}(\mathbf{5})(134 \mathrm{mg}$, $91 \%)$ as very dark red crystals $\left(\mathrm{CH}_{2} \mathrm{Cl}_{2} / \mathrm{MeOH}\right)$. Anal. Found: C, 55.19; H, 3.20. Calcd $\left(\mathrm{C}_{45} \mathrm{H}_{31} \mathrm{Co}_{3} \mathrm{FeO}_{7} \mathrm{P}_{2}\right): \mathrm{C}, 55.22 ; \mathrm{H}, 3.17 ; M, 978$. IR $\left(\mathrm{CH}_{2} \mathrm{Cl}_{2}, \mathrm{~cm}^{-1}\right): v(\mathrm{C} \equiv \mathrm{C})$ 
2123vw; v(CO) 2057s, 2007vs, 1988 (sh), 1965 (sh), 1948 (sh). ${ }^{1} \mathrm{H}$ NMR: $\delta 3.40,4.41$ ( 2 x s, 2 x 1H, dppm), 4.20 (s, 5H, Cp), 4.33, $4.48\left(2\right.$ x m, 2 x 2H, $\left.\mathrm{C}_{5} \mathrm{H}_{4}\right), 7.12-7.59(\mathrm{~m}$, 20H, Ph). ${ }^{13} \mathrm{C}$ NMR: $\delta 40.49$ [t, J(CP) $21.4 \mathrm{~Hz}, \mathrm{dppm}$ ], 69.84 (s, Cp), 69.14, 70.45 (2 x s, $\left.\mathrm{C}_{\mathrm{a}}, \mathrm{C}_{\mathrm{b}}, \mathrm{C}_{5} \mathrm{H}_{4}\right), 67.99\left(\mathrm{C}_{\mathrm{ipso}}, \mathrm{C}_{5} \mathrm{H}_{4}\right), 107.95,111.77$ (2 x s, chain carbons), 128.24-145.06 (m, $\mathrm{Ph}$ ), 202.44, 212.58, 226.21 [s (br), CO]. ${ }^{31}$ P NMR: $\delta 33.71$ (s, dppm). ES-MS (positive ion mode, $\mathrm{MeOH}, m / z$ ): $978, \mathrm{M}^{+}$; 950, $\left[\mathrm{M}-\mathrm{CO}^{+}\right.$; (negative ion, $\mathrm{MeOH}, m / z$ ): 977, [M $-\mathrm{H}]^{+}$.

(v) $\quad \mathrm{R}=\mathrm{Au}\left(\mathrm{PPh}_{3}\right)(\mathbf{6})$

A solution containing $4(100 \mathrm{mg}, 0.12 \mathrm{mmol})$ and $\mathrm{AuCl}\left(\mathrm{PPh}_{3}\right)(57 \mathrm{mg}, 0.12 \mathrm{mmol})$ in thf / $\mathrm{MeOH}(4 / 1,5 \mathrm{ml})$ was treated with $\mathrm{NaOMe}$ (from $\mathrm{Na}(6 \mathrm{mg})$ in $\mathrm{MeOH}(1 \mathrm{ml})]$ and the mixture was stirred at r.t. for $3 \mathrm{~h}$. After removal of solvent under vacuum, the brown residue was transferred to a sinter, washed with $\mathrm{MeOH}$ and hexane and dried.

Crystallisation $\left(\mathrm{CH}_{2} \mathrm{Cl}_{2} / \mathrm{MeOH}\right)$ gave $\mathrm{Co}_{3}\left\{\mu_{3}-\mathrm{CC} \equiv \mathrm{CAu}\left(\mathrm{PPh}_{3}\right)\right\}(\mu$-dppm $)(\mathrm{CO})_{7}(\mathbf{6})(130$ mg, 90\%) as dark red crystals. Anal. Found: C, 50.65; H, 3.02. Calcd $\left(\mathrm{C}_{53} \mathrm{H}_{37} \mathrm{AuCo}_{3} \mathrm{O}_{7} \mathrm{P}_{3}\right): \mathrm{C}, 50.80 ; \mathrm{H}, 2.95 ; M, 1252$. IR $\left(\mathrm{CH}_{2} \mathrm{Cl}_{2}, \mathrm{~cm}^{-1}\right): v(\mathrm{C} \equiv \mathrm{C}) 2137 \mathrm{vw}$; v(CO) 2053s, 2005vs, 1983 (sh), 1961 (sh); (cyclohexane): v(CO) 2061s, 2015vs, 2011vs, 1997m, 1984w, 1976m, 1960w. 'H NMR: $\delta 3.24,5.04$ (2 x s, 2 x 1H, dppm), 7.15-7.59(m, 35H, Ph). ${ }^{31} \mathrm{P}$ NMR: $\delta 32.53$ [s (br), dppm], 43.5 [s (br), $\mathrm{PPh}_{3}$ ]. ES-MS (positive ion, $\mathrm{MeOH}, m / z): 1253,[\mathrm{M}+\mathrm{H}]^{+} ;(\mathrm{MeOH}+\mathrm{NaOMe}, m / z): 1275,[\mathrm{M}+\mathrm{Na}]^{+}$

(vi) $\quad \mathrm{R}=\mathrm{C}_{6} \mathrm{H}_{4} \mathrm{C} \equiv \mathrm{CPh}(9)$

A mixture of $\mathrm{Au}\left(\mathrm{C} \equiv \mathrm{CC}_{6} \mathrm{H}_{4} \mathrm{C} \equiv \mathrm{CPh}-4\right)(90 \mathrm{mg}, 0.14 \mathrm{mmol}), \mathrm{Co}_{3}\left(\mu_{3}-\mathrm{CBr}\right)(\mu-\mathrm{dppm})(\mathrm{CO})_{7}$ (116 mg, $0.14 \mathrm{mmol}), \mathrm{Pd}\left(\mathrm{PPh}_{3}\right)_{4}(7.2 \mathrm{mg}, 0.006 \mathrm{mmol})$ and $\mathrm{CuI}(1.3 \mathrm{mg}, 0.006 \mathrm{mmol})$ in thf $(10 \mathrm{ml})$ was stirred at r.t. for $2.5 \mathrm{~h}$. After removal of solvent, the residue was extracted with $\mathrm{CH}_{2} \mathrm{Cl}_{2}$ and separated by preparative t.l.c. (hexane-acetone 10/1). The major brown band $\left(R_{\mathrm{f}} 0.56\right)$ contaned $\mathrm{Co}_{3}\left(\mu_{3}-\mathrm{CC} \equiv \mathrm{CC}_{6} \mathrm{H}_{4} \mathrm{C} \equiv \mathrm{CPh}\right)(\mu-\mathrm{dppm})(\mathrm{CO})_{7}(9)(51$ mg, 39\%) which was isolated as dark brown crystals $\left(\mathrm{CH}_{2} \mathrm{Cl}_{2} / \mathrm{MeOH}\right)$. Anal. Found: $\mathrm{C}$, 60.61; H, 3.17. Calcd $\left(\mathrm{C}_{49} \mathrm{H}_{31} \mathrm{Co}_{3} \mathrm{O}_{7} \mathrm{P}_{2}\right): \mathrm{C}, 60.62 ; \mathrm{H}, 3.19 ; M, 970$. IR $\left(\mathrm{CH}_{2} \mathrm{Cl}_{2}, \mathrm{~cm}^{-1}\right)$ : $v(\mathrm{C} \equiv \mathrm{C}) 2115 \mathrm{vw}, 2100 \mathrm{vw} ; \mathrm{v}(\mathrm{CO}) 2059 \mathrm{~s}, 2011 \mathrm{vs}, 1993$ (sh), 1967 (sh). ${ }^{1} \mathrm{H}$ NMR: $\delta$ 3.40, 4.43 (2 x s, 2 x 1H, dppm), 7.18-7.52 (m, 29H, Ph $\left.+\mathrm{C}_{6} \mathrm{H}_{4}\right) .{ }^{13} \mathrm{C}$ NMR: $\delta 41.27$ [t, 
$\left.J(\mathrm{CP}) 22.5 \mathrm{~Hz}, \mathrm{PCH}_{2}\right], 89.70,91.10\left(2 \mathrm{x} \mathrm{s}, \mathrm{C} \equiv \mathrm{CC}_{6} \mathrm{H}_{4} \mathrm{C} \equiv \mathrm{C}\right), 110.37$ (s, $\left.\mathrm{C}^{3}\right), 114.19$ (s, $\left.\mathrm{C}^{2}\right)$, 121.80-135.96 (m, Ph), 202.15, 210.05, 221.73 (3 x s, br, CO). ${ }^{31}$ P NMR: $\delta 34.3 \mathrm{~s}$. ESMS (positive ion, $\mathrm{MeOH}+\mathrm{NaOMe}, m / z$ ): $993,[\mathrm{M}+\mathrm{Na}]^{+}$; (negative ion, $\mathrm{MeOH}+$ $\mathrm{NaOMe}, m / z): 969,[\mathrm{M}-\mathrm{H}]$.

Preparation of $\left\{\mathrm{Co}_{3}(\mu-\mathrm{dppm})(\mathrm{CO})_{7}\right\}_{2}\left(\mu_{3}: \mu_{3}-\mathrm{CC} \equiv \mathrm{CC}_{6} \mathrm{H}_{4} \mathrm{C} \equiv \mathrm{CC}\right)(\mathbf{8})$

(a) A solution containing $\mathrm{Co}_{3}\left\{\mu_{3}-\mathrm{CC} \equiv \mathrm{CAu}\left(\mathrm{PPh}_{3}\right)\right\}(\mu-\mathrm{dppm})(\mathrm{CO})_{7}(50 \mathrm{mg}, 0.04 \mathrm{mmol})$, 1,4- $\mathrm{I}_{2} \mathrm{C}_{6} \mathrm{H}_{4}(6.4 \mathrm{mg}, 0.02 \mathrm{mmol}), \mathrm{Pd}\left(\mathrm{PPh}_{3}\right)_{4}(5 \mathrm{mg}, 0.004 \mathrm{mmol})$ and $\mathrm{CuI}(1 \mathrm{mg}, 0.006$ $\mathrm{mmol})$ in thf $(3 \mathrm{ml})$ was stirred at r.t. for $6 \mathrm{~h}$. After removal of solvent, the residue was extracted with $\mathrm{CH}_{2} \mathrm{Cl}_{2}$ and separated by preparative t.l.c. (acetone-hexane 3/7) into two fractions. Band $1\left(R_{\mathrm{f}} 0.50\right.$, green $)$ contained $\mathrm{Co}_{3}\left(\mu_{3}-\mathrm{CC} \equiv \mathrm{CC}_{6} \mathrm{H}_{4} \mathrm{I}-4\right)(\mu-\mathrm{dppm})(\mathrm{CO})_{7}(7)$ (12.2 mg, 61\%), obtained as very dark green crystals $\left(\mathrm{CH}_{2} \mathrm{Cl}_{2} / \mathrm{MeOH}\right)$. Anal. Found: $\mathrm{C}$, 49.65; H, 2.31. Calcd $\left(\mathrm{C}_{41} \mathrm{H}_{26} \mathrm{Co}_{3} \mathrm{IO}_{7} \mathrm{P}_{2}\right): \mathrm{C}, 49.40 ; \mathrm{H}, 2.61 ; M, 996$. IR $\left(\mathrm{CH}_{2} \mathrm{Cl}_{2}, \mathrm{~cm}^{-1}\right)$ : $v(\mathrm{C} \equiv \mathrm{C}) 2117 \mathrm{vw} ; \quad v(\mathrm{CO}) 2060 \mathrm{~s}, 2010 \mathrm{vs}, 1980$ (sh), 1967 (sh), 1949 (sh). ${ }^{1} \mathrm{H}$ NMR: $\delta$ 3.40, 4.37 (2 x s, 2 x 1H, dppm), 7.05-7.69 (m, 24H, Ph $\left.+\mathrm{C}_{6} \mathrm{H}_{4}\right) \cdot{ }^{31} \mathrm{P}$ NMR: $\delta 34.32[\mathrm{~s}$ (br), dppm]. ES-MS (positive ion, $\mathrm{MeOH}+\mathrm{NaOMe}, \mathrm{m} / \mathrm{z}$ ): 1019, $[\mathrm{M}+\mathrm{Na}]^{+}$; (negative ion, $\mathrm{MeOH}, \mathrm{m} / \mathrm{z}$ ): 995, [M $-\mathrm{H}]$; 968, [M $-\mathrm{H}-\mathrm{CO}]$. The second orange-brown band $\left(R_{\mathrm{f}} 0.45\right)$ contained $\left\{\mathrm{Co}_{3}(\mu-\mathrm{dppm})(\mathrm{CO})_{7}\right\}_{2}\left(\mu_{3}: \mu_{3}-\mathrm{CC} \equiv \mathrm{CC}_{6} \mathrm{H}_{4} \mathrm{C} \equiv \mathrm{CC}\right)(\mathbf{8})(3.6 \mathrm{mg}, 11 \%)$. Anal. Calcd $\left(\mathrm{C}_{76} \mathrm{H}_{48} \mathrm{Co}_{6} \mathrm{O}_{14} \mathrm{P}_{4}\right): \mathrm{C}, 54.87 ; \mathrm{H}, 2.89 ; \mathrm{M}, 1662$. Found: C, 54.92; H, 2.75. IR $\left(\mathrm{CH}_{2} \mathrm{Cl}_{2}, \mathrm{~cm}^{-1}\right): 2063 \mathrm{~s}, 2016 \mathrm{~s}, 1984 \mathrm{~m}, 1905 \mathrm{~m} .{ }^{1} \mathrm{H}$ NMR: $\delta 3.42,4.44(2 \mathrm{x} \mathrm{m}, 2$ x 2H, $\mathrm{CH}_{2}$ ), 7.18-7.50 (m, 44H, $\left.\mathrm{Ph}+\mathrm{C}_{6} \mathrm{H}_{4}\right) .{ }^{31} \mathrm{P}$ NMR: $\delta 35.07$ (s, dppm). ES MS (positive ion, $\mathrm{MeOH}+\mathrm{NaOMe}, m / z)$ : $1685,[\mathrm{M}+\mathrm{Na}]^{+}$; (negative ion, $\mathrm{MeOH}+\mathrm{NaOMe}, m / z$ ): 1661, [M - H] .

(b) A mixture of 1,4- $\left\{\mathrm{AuPPh}_{3}(\mathrm{C} \equiv \mathrm{C})\right\}_{2} \mathrm{C}_{6} \mathrm{H}_{4}(30 \mathrm{mg}, 0.03 \mathrm{mmol}), \mathrm{Co}_{3}\left(\mu_{3}-\mathrm{CBr}\right)(\mu-$ $\mathrm{dppm})(\mathrm{CO})_{7}(98 \mathrm{mg}, 0.06 \mathrm{mmol}), \mathrm{Pd}\left(\mathrm{PPh}_{3}\right)_{4}(15 \mathrm{mg}, 0.013 \mathrm{mmol})$ and $\mathrm{CuI}(5 \mathrm{mg}, 0.026$ $\mathrm{mmol})$ was stirred in thf $(20 \mathrm{ml})$ at r.t. for $1 \mathrm{~h}$. The solvent was then removed and the resulting dark purple residue purified by preparative t.l.c. eluting with acetone / hexane (2:3) to obtain $1,4-\left\{\mathrm{Co}_{3} \mathrm{C}(\mathrm{C} \equiv \mathrm{C})(\mu-\mathrm{dppm})(\mathrm{CO})_{7}\right\}_{2} \mathrm{C}_{6} \mathrm{H}_{4}$ as an orange band $\left(R_{\mathrm{f}} 0.68\right)$ (20.3 $\mathrm{mg}, 41 \%)$. Anal. Calcd $\left(\mathrm{C}_{76} \mathrm{H}_{48} \mathrm{P}_{4} \mathrm{Co}_{6} \mathrm{O}_{14}\right): \mathrm{C}, 54.87 ; \mathrm{H}, 2.89$. Found: $\mathrm{C}, 54.92 ; \mathrm{H}, 2.75$. IR $\left(\mathrm{CH}_{2} \mathrm{Cl}_{2}, \mathrm{~cm}^{-1}\right): v(\mathrm{C} \equiv \mathrm{C}) 2114 \mathrm{w}, \mathrm{v}(\mathrm{CO}) 2059 \mathrm{~s}, 2010 \mathrm{vs} 1993 \mathrm{sh}(\mathrm{m}), 1969 \mathrm{sh}(\mathrm{w}) .{ }^{31} \mathrm{P}$ 
$\mathrm{NMR}\left(\mathrm{CDCl}_{3}\right): \delta 37.01$ (s(br), 4P, dppm). ES MS (positive ion, $\left.\mathrm{MeOH}+\mathrm{NaOMe}, m / z\right)$ : $1685[\mathrm{M}+\mathrm{Na}]^{+}$; (negative ion, $\left.\mathrm{MeOH}, m / z\right)$ : 1661, $[\mathrm{M}-\mathrm{H}]^{-}$.

Reaction of $1,3,5-\left\{\left(\mathrm{Ph}_{3} \mathrm{P}\right) \mathrm{AuC} \equiv \mathrm{C}\right\}_{3} \mathrm{C}_{6} \mathrm{H}_{3}$ with $\mathrm{Co}_{3}\left(\mu_{3}-\mathrm{CBr}\right)(\mu-\mathrm{dppm})(\mathrm{CO})_{7}$

(a) A solution of $1,3,5-\left\{\left(\mathrm{Ph}_{3} \mathrm{P}\right) \mathrm{AuC} \equiv \mathrm{C}\right\}_{3} \mathrm{C}_{6} \mathrm{H}_{3}(59.7 \mathrm{mg}, 0.039 \mathrm{mmol})$ and $\mathrm{Co}_{3}\left(\mu_{3}-\right.$ $\mathrm{CBr})(\mu-\mathrm{dppm})(\mathrm{CO})_{7}(100 \mathrm{mg}, 0.118 \mathrm{mmol})$ in thf $(10 \mathrm{ml})$ was treated with $\mathrm{Pd}\left(\mathrm{PPh}_{3}\right)_{4}(4.5$ $\mathrm{mg}, 0.0035 \mathrm{mmol})$ and $\mathrm{CuI}(1 \mathrm{mg}, 0.005 \mathrm{mmol})$ and the mixture was stirred at r.t. for $4 \mathrm{~h}$. After removal of solvent under vacuum and a $\mathrm{CH}_{2} \mathrm{Cl}_{2}$ extract of the residue was purified by preparative $\mathrm{t} / \mathrm{l} / \mathrm{c} /$ (acetone-hexane, $3 / 7)$. The major brown band $\left(R_{\mathrm{f}} 0.40\right)$ contained $1,3,5-\left\{\mathrm{Co}(\mu-\mathrm{dppm})(\mathrm{CO})_{7}\right\}_{3} \mathrm{C}_{6} \mathrm{H}_{3}(\mathbf{1 0})(48.8 \mathrm{mg}, 50 \%)$, obtained as dark red crystals $\left(\mathrm{CHCl}_{3} / \mathrm{MeOH}\right)$. Anal. Found: $\mathrm{C}, 54.80 ; \mathrm{H}, 2.83$. Calcd $\left(\mathrm{C}_{111} \mathrm{H}_{69} \mathrm{Co}_{9} \mathrm{O}_{21} \mathrm{P}_{6}\right): \mathrm{C}, 54.28$; H, 2.83; M, 2454. IR $\left(\mathrm{CH}_{2} \mathrm{Cl}_{2}, \mathrm{~cm}^{-1}\right): v(\mathrm{CC}) 2115 \mathrm{w} ; v(\mathrm{CO}) 2059 \mathrm{~s}, 2010 \mathrm{vs}, 1990$ (sh), 1969 (sh), 1953 (sh). ${ }^{1} \mathrm{H}$ NMR: $\delta 3.46,4.43$ (2 x m, 2 x 3H, $\mathrm{CH}_{2}$ ), 7.17-7.58 (m, 63H, $\left.\mathrm{Ph}+\mathrm{C}_{6} \mathrm{H}_{3}\right) .{ }^{13} \mathrm{C}$ NMR: $\delta 40.81\left[\mathrm{~s}(\mathrm{br}), \mathrm{CH}_{2}\right], 108.92,112.76$ (2 x s, 2 x C of $\mathrm{C}_{3}$ chain), 126.54-132.17 (m, $\left.\mathrm{Ph}+\mathrm{C}_{6} \mathrm{H}_{3}\right), 202.24$ [s (br), CO]. ${ }^{31} \mathrm{P}$ NMR: $\delta 34.95$ [s (br), dppm]. ES MS (positive ion, $\mathrm{MeOH}, m / z): 2454, \mathrm{M}^{+} ;(\mathrm{MeOH}+\mathrm{NaOMe}, m / z): 2477,[\mathrm{M}+$ $\mathrm{Na}]^{+}$.

(b) From a sample of $1,3,5-\left\{\left(\mathrm{Ph}_{3} \mathrm{P}\right) \mathrm{AuC} \equiv \mathrm{C}\right\}_{3} \mathrm{C}_{6} \mathrm{H}_{3}$ containing a significant amount of $1,3-\left\{\left(\mathrm{Ph}_{3} \mathrm{P}\right) \mathrm{AuC} \equiv \mathrm{C}\right\}_{3} \mathrm{C}_{6} \mathrm{H}_{3} \mathrm{Br}-5$, a similar reaction with $\mathrm{Co}_{3}\left(\mu_{3}-\mathrm{CBr}\right)(\mu-\mathrm{dppm})(\mathrm{CO})_{7}(33$ $\mathrm{mg}, 0.039 \mathrm{mmol}$ ) was carried out with the addition of a few drops of dbu. After $2 \mathrm{~h}$ at r.t., work-up as above afforded a green-brown band $\left(R_{\mathrm{f}} 0.47\right)$ which contained $1,3-\{\mathrm{Co}(\mu-$ dppm) $\left.(\mathrm{CO})_{7}\right\}_{3} \mathrm{C}_{6} \mathrm{H}_{3} \mathrm{Br}-5$ (11) (10.8 mg), obtained as brown-red crystals $\left(\mathrm{CH}_{2} \mathrm{Cl}_{2} / \mathrm{MeOH}\right)$. Anal. Found: C, 52.34; H, 2.61. Calcd $\left(\mathrm{C}_{76} \mathrm{H}_{47} \mathrm{Co}_{6} \mathrm{O}_{14} \mathrm{P}_{4}\right)$ : C, 52.38; H, 2.69; M, 1741. IR $\left(\mathrm{CH}_{2} \mathrm{Cl}_{2}, \mathrm{~cm}^{-1}\right)$ : v(CC) 2114w; v(CO) 2057s, 2009vs, 1988 (sh), 1970 (sh), 1951 (sh). ${ }^{1} \mathrm{H}$ NMR: $\delta$ 3.40, $4.41\left(2 \times \mathrm{m}, 2 \times 2 \mathrm{H}, \mathrm{CH}_{2}\right), 6.95-7.51\left(\mathrm{~m}, 43 \mathrm{H}, \mathrm{Ph}+\mathrm{C}_{6} \mathrm{H}_{3}\right) .{ }^{31} \mathrm{P} \mathrm{NMR}: \delta$ 35.21 [s (br), dppm]. ES MS (positive ion, $\mathrm{MeOH}+\mathrm{NaOMe}, m / z): 1764,[\mathrm{M}+\mathrm{Na}]^{+}$; (negative ion, $\mathrm{MeOH}+\mathrm{NaOMe}, \mathrm{m} / z$ ): $1741, \mathrm{M}$.

$\left\{\mathrm{Co}_{3}(\mu-\mathrm{dppm})(\mathrm{CO})_{7}\right\}\left(\mu_{3}: \mu_{3}-\mathrm{CC} \equiv \mathrm{CFc}^{\prime} \mathrm{C} \equiv \mathrm{CC}\right)(\mathbf{1 2})$ 
A solution containing $1,1^{\prime}-\mathrm{Fc}^{\prime}\left\{\mathrm{C} \equiv \mathrm{CAu}\left[\mathrm{P}(\mathrm{tol})_{3}\right]\right\}_{2}(26 \mathrm{mg}, 0.02 \mathrm{mmol}), \mathrm{Co}_{3}\left(\mu_{3}-\mathrm{CBr}\right)(\mu-$ $\mathrm{dppm})(\mathrm{CO})_{7}(36 \mathrm{mg}, 0.04 \mathrm{mmol}), \mathrm{Pd}\left(\mathrm{PPh}_{3}\right)_{4}(1 \mathrm{mg}, 0.001 \mathrm{mmol})$ and $\mathrm{CuI}(1 \mathrm{mg}, 0.005$ $\mathrm{mmol})$ in thf $(5 \mathrm{ml})$ was stirred at r.t. for $2 \mathrm{~h}$. After removal of solvent, the residue was extracted with $\mathrm{CH}_{2} \mathrm{Cl}_{2}$ and purified by preparative t.l.c. (acetone-hexane 3/7) to give one major band $\left(R_{\mathrm{f}} 0.34\right)$, from which $\left\{\mathrm{Co}_{3}(\mu-\mathrm{dppm})(\mathrm{CO})_{7}\right\}\left(\mu_{3}: \mu_{3}-\mathrm{CC} \equiv \mathrm{CFc}{ }^{\prime} \mathrm{C} \equiv \mathrm{CC}\right)(\mathbf{1 2})(35.7$ $\mathrm{mg}, 96 \%)$ was isolated as very dark red crystals $\left(\mathrm{CH}_{2} \mathrm{Cl}_{2} / \mathrm{MeOH}\right)$. Anal. Found: $\mathrm{C}$, 54.26; H, 2.96. Calcd $\left(\mathrm{C}_{80} \mathrm{H}_{52} \mathrm{Co}_{6} \mathrm{FeO}_{14} \mathrm{P}_{4}\right): \mathrm{C}, 54.23 ; \mathrm{H}, 2.94 ; M, 1770 . \mathrm{IR}\left(\mathrm{CH}_{2} \mathrm{Cl}_{2}, \mathrm{~cm}\right.$ $\left.{ }^{1}\right): v(\mathrm{C} \equiv \mathrm{C}) 2122 \mathrm{vw} ; \mathrm{v}(\mathrm{CO}) 2057 \mathrm{~s}, 2008 \mathrm{vs}, 1989$ (sh), 1977 (sh), 1964 (sh). ${ }^{1} \mathrm{H}$ NMR: $\delta$ 3.43, $4.44\left(2\right.$ x s, 2 x 1H, dppm), 4.40, $4.53\left(2 \times \mathrm{m}, 2\right.$ x 4H, $\left.\mathrm{C}_{5} \mathrm{H}_{4}\right), 7.11-7.52(\mathrm{~m}, 40 \mathrm{H}$, $\mathrm{Ph}$ ). ${ }^{31} \mathrm{P}$ NMR: $\delta 33.68$ [s (br), dppm]. ES-MS (positive ion, $\mathrm{MeOH}+\mathrm{NaOMe}, m / z$ ): 1793, $[\mathrm{M}+\mathrm{Na}]^{+}$; (negative ion, $\left.\mathrm{MeOH}, m / z\right)$ : 1769, [M-H] .

$\mathrm{Co}_{3}\left\{\mu_{3}-C(C \equiv C)_{n} R\right\}(\mu-d p p m)(C O)_{7}, n=3$

(i) $\quad \mathrm{R}=\mathrm{SiMe}_{3}(\mathbf{1 3})$

A mixture of $\mathrm{Co}_{3}\left\{\mu_{3}-\mathrm{C}\left(\mathrm{C} \equiv \mathrm{CC} \equiv \mathrm{CAu}\left(\mathrm{PPh}_{3}\right)\right\}(\mu-\mathrm{dppm})(\mathrm{CO})_{7}(280 \mathrm{mg}, 0.219 \mathrm{mmol})\right.$, $\mathrm{IC} \equiv \mathrm{CSiMe}_{3}(85 \mathrm{mg}, 0.379 \mathrm{mmol}), \mathrm{Pd}\left(\mathrm{PPh}_{3}\right)_{4}(13 \mathrm{mg}, 0.01 \mathrm{mmol})$ and $\mathrm{CuI}(2 \mathrm{mg}, 0.01$ $\mathrm{mmol})$ in thf $(10 \mathrm{ml})$ was stirred at r.t. for $2 \mathrm{~h}$. After removal of solvent, preparative t.l.c. (acetone-hexane 1/2) of a $\mathrm{CH}_{2} \mathrm{Cl}_{2}$ extract of the residue developed two bands. Band $1\left(R_{\mathrm{f}}\right.$ 0.55, brown) contained $\mathrm{Co}_{3}\left\{\mu_{3}-\mathrm{C}(\mathrm{C} \equiv \mathrm{C})_{3} \mathrm{SiMe}_{3}\right\}(\mu-\mathrm{dppm})(\mathrm{CO})_{7}(\mathbf{1 3})(108 \mathrm{mg}, 54 \%)$, obtained a brown-black crystals from $\mathrm{CH}_{2} \mathrm{Cl}_{2} / \mathrm{MeOH}$. Anal. Found: C, 55.20; H, 3.48. Calcd $\left(\mathrm{C}_{42} \mathrm{H}_{31} \mathrm{Co}_{3} \mathrm{O}_{7} \mathrm{P}_{2} \mathrm{Si}\right): \mathrm{C}, 55.16 ; \mathrm{H}, 3.42 ; M$, 914. IR $\left(\mathrm{CH}_{2} \mathrm{Cl}_{2}, \mathrm{~cm}^{-1}\right): v(\mathrm{C} \equiv \mathrm{C})$ 2134vw; v(CO) 2062s, 2018vs, 1974 (sh). ${ }^{~} \mathrm{H}$ NMR: $\delta 0.26$ (s, 9H, $\mathrm{SiMe}_{3}$ ), 3.41, 4.24 (2 x s, 2 x 1H, dppm), 7.20-7.41 (m, 20H, Ph). ${ }^{31}$ P NMR: $\delta 34.64$ (s, dppm). ES-MS (positive ion, $\mathrm{MeOH}+\mathrm{NaOMe}, \mathrm{m} / z$ ): 937, $[\mathrm{M}+\mathrm{Na}]^{+} ; 915,[\mathrm{M}+\mathrm{H}]^{+} ; 865,[\mathrm{M}+\mathrm{H}+$ $\left.\mathrm{Na}-\mathrm{SiMe}_{3}\right]^{+}$; (negative ion, $\mathrm{MeOH}+\mathrm{NaOMe}, \mathrm{m} / z$ ): 913, [M - H] ; 841, [M- $\left.\mathrm{SiMe}_{3}\right]$; 814, $\left[\mathrm{M}+\mathrm{H}-\mathrm{CO}-\mathrm{SiMe}_{3}\right]$. Band $2\left(R_{\mathrm{f}} 0.38\right.$, red-brown $)$ contained $\left\{\mathrm{Co}_{3}(\mu-\right.$ $\left.\mathrm{dppm})(\mathrm{CO})_{7}\right\}_{2}\left(\mu_{3}: \mu_{3}-\mathrm{C}_{10}\right)$, identified by comparison with an authentic sample. ${ }^{10 a}$

(ii) $\mathrm{R}=\mathrm{Fc}(\mathbf{1 4})$ A mixture of $\left.\left.\mathrm{Co}_{3}\left\{\mu_{3}-\mathrm{CC} \equiv \mathrm{CC} \equiv \mathrm{CAu}\left(\mathrm{PPh}_{3}\right)\right\} \mu-\mathrm{dppm}\right)(\mathrm{CO})_{7}\right\}$ (60 mg, $\left.0.05 \mathrm{mmol}\right), \mathrm{FcC} \equiv \mathrm{CI}$ (15.3 mg, $0.05 \mathrm{mmol}), \mathrm{Pd}\left(\mathrm{PPh}_{3}\right)_{4}(3 \mathrm{mg}, 0.0025 \mathrm{mmol})$ and $\mathrm{CuI}(1 \mathrm{mg}, 0.005 \mathrm{mmol})$ in 
thf $(7 \mathrm{ml})$ was stirred at r.t. for $30 \mathrm{~min}$. Evaporation and purification of the residue by preparative t.l.c. (acetone/hexane 1/4) gave three bands. The fastest moving $\left(R_{\mathrm{f}} 0.93\right)$ contained $\mathrm{FcC} \equiv \mathrm{CC} \equiv \mathrm{CFc}(2 \mathrm{mg}, 5 \%)$, identified by comparison with an authentic sample. The major product was contained in the second brown-orange band $\left(R_{\mathrm{f}} 0.26\right)$, which gave $\mathrm{Co}_{3}\left\{\mu_{3}-\mathrm{C}(\mathrm{C} \equiv \mathrm{C})_{3} \mathrm{Fc}\right\}(\mu-\mathrm{dppm})(\mathrm{CO})_{7}(\mathbf{1 4})(40.8 \mathrm{mg}, 87.4 \%)$ as very thin red plates $\left(\mathrm{CH}_{2} \mathrm{Cl}_{2}\right.$ / hexane). Anal. Found: C, 56.74; H, 2.57. Calcd $\left(\mathrm{C}_{49} \mathrm{H}_{31} \mathrm{Co}_{3} \mathrm{FeO}_{7} \mathrm{P}_{2}\right): \mathrm{C}, 57.31 ; \mathrm{H}$, 3.02\%; M, 1026. IR $\left(\mathrm{CH}_{2} \mathrm{Cl}_{2}, \mathrm{~cm}^{-1}\right): v(\mathrm{C} \equiv \mathrm{C}) 2168 \mathrm{w}, 2100 \mathrm{vw} ; \mathrm{v}(\mathrm{CO}) 2063 \mathrm{~s}, 2013 \mathrm{vs}$, 1973 (sh), 1958 (sh) $\mathrm{cm}^{-1} .{ }^{1} \mathrm{H}$ NMR: $\delta 3.40,4.25$ (2 x m, 2 x 1H, $\mathrm{CH}_{2}$ ), 4.28 (s, 5H, Cp), 4.30, $4.56\left(2 \times \mathrm{m}, 2 \times 2 \mathrm{H}, \mathrm{C}_{5} \mathrm{H}_{4}\right), 7.15-7.69(\mathrm{~m}, 20 \mathrm{H}, \mathrm{Ph}) .{ }^{13} \mathrm{C} \mathrm{NMR}: \delta 42.75[\mathrm{t}, J(\mathrm{CP})$ 18.3, $\left.\mathrm{CH}_{2} \mathrm{P}\right], 70.35$ (s, Cp), 69.76, 72.35 (2 x m, $\left.\mathrm{C}_{5} \mathrm{H}_{4}\right), 63.38,65.66,72.73,80.95,85.99$, 97.13, $99.03\left(\mathrm{C}_{\mathrm{ipso}}+\right.$ six $\mathrm{C}$ of $\mathrm{C}_{7}$ chain), 201.43, 209.79, 212.4 (3 x s, CO). ${ }^{31} \mathrm{P}$ NMR: $\delta$ 33.78 (s, dppm). ES-MS (positive ion, $\mathrm{MeOH}, m / z): 1027,[\mathrm{M}+\mathrm{H}]^{+} ; 1026,[\mathrm{M}]^{+} ; 998$, $[\mathrm{M}-\mathrm{CO}]^{+}$; (positive ion, $\left.\mathrm{MeOH}+\mathrm{NaOMe}, m / z\right)$ ) 1049, $[\mathrm{M}+\mathrm{Na}]^{+}$; (negative ion, $\mathrm{MeOH}+\mathrm{NaOMe}, m / z): 1026+1025$, overlapping $[\mathrm{M}]^{+}+[\mathrm{M}-\mathrm{H}]^{+}$. The third band $\left(R_{\mathrm{f}}\right.$ 0.15 , brown-orange) contained $\left\{\mathrm{Co}_{3}(\mu-\mathrm{dppm})(\mathrm{CO})_{7}\right\}_{2}\left(\mu_{3}: \mu_{3}-\mathrm{C}_{10}\right)(0.6 \mathrm{mg}, 1 \%)$, identified by comparison with an authentic sample. ${ }^{10 a}$

(iii) $\mathrm{R}=\mathrm{Au}\left(\mathrm{PPh}_{3}\right)(\mathbf{1 5})$

$\mathrm{NaOMe}$ [from $10 \mathrm{mg} \mathrm{Na}$ in $\mathrm{MeOH}(10 \mathrm{ml})]$ was added to a solution of $\mathrm{Co}_{3}\left\{\mu_{3}\right.$ $\left.\mathrm{C}(\mathrm{C} \equiv \mathrm{C})_{3} \mathrm{SiMe}_{3}\right\}(\mu-\mathrm{dppm})(\mathrm{CO})_{7}(84 \mathrm{mg}, 0.092 \mathrm{mmol})$ in thf $/ \mathrm{MeOH}(1 / 1,10 \mathrm{ml})$, and after stirring for $10 \mathrm{~min}$ at r.t., $\mathrm{AuCl}\left(\mathrm{PPh}_{3}\right)(46 \mathrm{mg}, 0.093 \mathrm{mmol})$ was added. A brown precipitate separated and after stirring at r.t. for $1 \mathrm{~h}$, the precipitate was collected and washed with $\mathrm{MeOH}(2 \times 2 \mathrm{ml})$ affording $\mathrm{Co}_{3}\left\{\mu_{3}-\mathrm{C}(\mathrm{C} \equiv \mathrm{C})_{3} \mathrm{Au}\left(\mathrm{PPh}_{3}\right)\right\}(\mu-\mathrm{dppm})(\mathrm{CO})_{7}(\mathbf{1 5})$ (90 mg, 75\%) as a brown powder. Anal. Found: C, 52.59; H, 2.83. Calcd $\left(\mathrm{C}_{57} \mathrm{H}_{37} \mathrm{AuCo}_{3} \mathrm{O}_{7} \mathrm{P}_{3}\right): \mathrm{C}, 52.64 ; \mathrm{H}, 2.87 ; M, 1300$. IR $\left(\mathrm{CH}_{2} \mathrm{Cl}_{2}, \mathrm{~cm}^{-1}\right): \mathrm{v}(\mathrm{C} \equiv \mathrm{C}) 2117 \mathrm{vw}$; v(CO) 2060s, 2012vs, 1974 (sh). ${ }^{1} \mathrm{H}$ NMR: $\delta 3.40,4.34$ (2 x s, 2 x 1H, dppm), 7.18-7.56 (m, 35H, Ph). ${ }^{13} \mathrm{C}$ NMR: $\delta 42.63\left(\mathrm{~m}, \mathrm{CH}_{2}\right), 57.49,82.83,88.79,95.20,98.81(5 \mathrm{x} \mathrm{s}$, carbon chain), 128.38-131.86 (m, Ph), 134.20-134.52 (m, Ph), 201.52 (br, CO). ${ }^{31} \mathrm{P}$ NMR: $\delta 34.69$ [s (br), dppm)]. ES-MS (positive ion, $\mathrm{MeOH}+\mathrm{NaOMe}, m / z): 1323,[\mathrm{M}+\mathrm{Na}]^{+}$.

$$
\text { (iv) } \mathrm{R}=\mathrm{Ph}(\mathbf{1 6})
$$


A solution containing $\mathrm{Co}_{3}\left\{\mu_{3}-\mathrm{CC} \equiv \mathrm{CC} \equiv \mathrm{CAu}\left(\mathrm{PPh}_{3}\right)\right\} \mu$-dppm $\left.)(\mathrm{CO})_{7}\right\}(50 \mathrm{mg}, 0.04 \mathrm{mmol})$ and $\mathrm{Pd}\left(\mathrm{PPh}_{3}\right)_{4}(00 \mathrm{mg}, 00 \mathrm{mmol})$ in thf $(5 \mathrm{ml})$ was added to a mixture of iodine $(10 \mathrm{mg}$, $0.04 \mathrm{mmol})$ and $\mathrm{CuI}(00 \mathrm{mg}, 00 \mathrm{mmol})$ in thf $(5 \mathrm{ml})$ at $-78^{\circ} \mathrm{C}$, and the mixture was stirred for $1 \mathrm{~h}$. After this time, a soluton of $\mathrm{Au}(\mathrm{C} \equiv \mathrm{CPh})\left(\mathrm{PPh}_{3}\right)(20 \mathrm{mg}, 0.04 \mathrm{mmol})$ in thf $(5 \mathrm{ml})$ was added dropwise and the mixture was stirred for a further $1 \mathrm{~h}$ at $-78^{\circ} \mathrm{C}$. After allowing to warm to r.t., the filtered soluton was evaporated and the residue was extracted into $\mathrm{CH}_{2} \mathrm{Cl}_{2}$ and purified by preparative t.l.c. (acetone-hexane 3/7). The brown band ( $\mathrm{Rf}$ 0.76) contained $\mathrm{Co}_{3}\left\{\mu_{3}-\mathrm{C}(\mathrm{C} \equiv \mathrm{C})_{3} \mathrm{Ph}\right\}(\mu-\mathrm{dppm})(\mathrm{CO})_{7}(\mathbf{1 6})(21 \mathrm{mg}, 60 \%)$, obtained as black needles $\left(\mathrm{CH}_{2} \mathrm{Cl}_{2} / \mathrm{MeOH}\right)$. Anal. Found: C, 58.98; H, 2.87. Calcd $\left(\mathrm{C}_{45} \mathrm{H}_{27} \mathrm{Co}_{3} \mathrm{O}_{7} \mathrm{P}_{2}\right)$ : C, 58.82; H, 2.94\%; M, 918. IR $\left(\mathrm{CH}_{2} \mathrm{Cl}_{2}, \mathrm{~cm}^{-1}\right): v(\mathrm{C} \equiv \mathrm{C}) 2190 \mathrm{w}, 2171 \mathrm{vw} ; v(\mathrm{CO}) 2065 \mathrm{~s}$, 2040m, 2014m, 1973 (sh), 1955 (sh) $\mathrm{cm}^{-1} .{ }^{1} \mathrm{H}$ NMR: $\delta 3.30,4.15$ (2 x m, 2 x 1H, dppm), 7.09-7.47 (m, 25H, Ph). ${ }^{31} \mathrm{P}$ NMR: $\delta 34.63$ (s, dppm). ES-MS (positive ion, $\mathrm{MeOH}+$ $\mathrm{NaOMe}, m / z): 941,[\mathrm{M}+\mathrm{Na}]^{+}$; (negative ion, $\left.\mathrm{MeOH}, m / z\right): 918, \mathrm{M} ; 917,[\mathrm{M}-\mathrm{H}]$; 890, $[\mathrm{M}-\mathrm{CO}]^{-}$.

\section{Structure determinations}

Full spheres of diffraction data were measured at ca $153 \mathrm{~K}$ using a Bruker AXS CCD area-detector instrument. $N_{\text {tot }}$ reflections were merged to $N$ unique $\left(R_{\text {int }}\right.$ cited $)$ after "empirical" / multiscan absorption correction (proprietary software), $N_{\mathrm{o}}$ with $F>4 \sigma(F)$ being used in the full matrix least squares refinements. All data were measured using monochromatic Mo-Ka radiation, $\lambda=0.71073 \AA$ A. Anisotropic displacement parameter forms were refined for the non-hydrogen atoms, $\left(x, y, z, U_{\text {iso }}\right)_{\mathrm{h}}$ being refined.

Conventional residuals $R, R_{\mathrm{w}}$ on $|F|$ are quoted [weights: $\left(\sigma^{2}(F)+0.000 n_{\mathrm{w}} F^{2}\right)^{-1}$ ]. Neutral atom complex scattering factors were used; computation used the XTAL 3.7 program system. ${ }^{39}$ Pertinent results are given in the figures (which show non-hydrogen atoms with $50 \%$ probability amplitude displacement ellipsoids and hydrogen atoms with arbitrary radii of $0.1 \AA$ ) and in Tables 1 and 2 .

Variata. 4. $\left(x, y, z, U_{\text {iso }}\right)_{\mathrm{H}}$ were refined throughout; it is isomorphous with 2 and was refined in the same cell and coordinate setting. 
5. The iron atoms of both molecules were modelled as disordered over pairs of sites, occupancies refining in concert to $0.888(3)$ and complement. Fe ... Fe are 0.88(1) and 0.86(1) $\AA$; minor components of the associated Cp ligands were not located.

10. Weak and limited data resulted in a determination of inferior precision.

11. The dichloromethane of solvation was modelled as disordered over two sets of sites, occupancies 0.694(5) and complement.

\section{Supplementary material}

Full details of the structure determinations (except structure factors) have been deposited with the Cambridge Crystallographic Data Centre as CCDC \#. Copies of this information may be obtained free of charge from The Director, CCDC, 12 Union Road, Cambridge CB2 1EZ, UK (Fax: + 441223336 033; e-mail: deposit@ccdc.cam.ac.uk or www: http://www.ccdc.cam.ac.uk).

\section{Acknowledgements}

We thank the ARC for support of this work.

\section{References}

1 Bredas, J.L.; Chance, R.R. (eds), Conjugated Polymeric Materials: Opportunities in Electronics, Optoelectronics and Molecular Electronics, Kluwer: Dordrecht, 1990.

2 Paul, F.; Lapinte, C. in Gielen, M.; Willem, R.; Wrackmeyer, B. (eds), Unusual Structures and Physical Properties in Organometallic Chemistry, Wiley: New York, 2002, p. 220.

3 Paul, F.; Lapinte, C. Coord. Chem. Rev., 1978, 178-180, 431.

4 Bruce, M.I.; Low, P.J. Adv. Organomet. Chem., 2004, 50, 179.

5 Woodworth, B.E.; Templeton, J.L. J. Am. Chem. Soc., 1996, 118, 7418.

6 (a) Weng, W.; Ramsden, J.A.; Arif, A.M.; Gladysz, J.A. J. Am. Chem. Soc., 1993, 115, 3824. (b) Bartik, T.; Weng, W.; Ramsden, J.A.; Szafert, S.; Falloon, S.B.; Arif, A.M.; Gladysz, J.A. J. Am. Chem. Soc., 1998, 120, 11071. (c) Weng, W.; Bartik, T.; Gladysz, J.A. Angew. Chem., 1994, 106, 2272; Angew. Chem., Int. Ed. Engl., 1994, 33, 2199. 
7 Dembinski, R.; Szafert, S.; Haquette, P.; Lis, T.; Gladysz, J.A.

Organometallics, 1999, 18, 5438.

8 (a) Dewhirst, R.D.; Hill, A.F.; Smith, M.K. Angew. Chem. Int. Ed., 2004, 43, 476. (b) Dewhirst, R.D.; Hill, A.F.; Willis, A.C. Organometallics, 2004, 23, 1646. (c) Dewhirst, R.D.; Hill, A.F.; Willis, A.C. Organometallics, 2004, 23, 5903. (d) Dewhirst, R.D.; Hill, A.F.; Willis, A.C. Chem. Commun., 2004, 2826.

9 Bruce, M.I.; Humphrey, P.A.; Melino, G.; Skelton, B.W.; White, A.H.; Zaitseva, N.N. Inorg. Chim. Acta, 2005, 358, 1453.

10 (a) Bruce, M.I.; Smith, M.E.; Zaitseva, N.N.; Skelton, B.W.; White, A.H. J. Organomet. Chem., 2003, 670, 170. (b) Bruce, M.I.; Skelton, B.W.; White, A.H.; Zaitseva, N.N. J. Organomet. Chem., 2003, 683, 398.

11 Markby, R.; Wender, I.; Friedel, R.A.; Cotton, F.A.; Sternberg, H.W. J. Am. Chem. Soc., 1958, 80, 6529.

12 Palyi, G.; Piacenti, F.; Marko, L. Inorg. Chim. Acta Rev., 1970, 4, 109.

13 Penfold, B.R.; Robinson, B.H. Acc. Chem. Res., 1973, 6, 73.

14 Seyferth, D. Adv. Organomet. Chem., 1976, 14, 97.

15 Schmid, G. Angew. Chem., 1978, 90, 417; Angew. Chem., Int. Ed. Engl., 1978, 17, 392.

16 Kemmitt, R.D.W. in Wilkinson, G.; Stone, F.G.A.; Abel, E.W. (eds), Comprehensive Organometallic Chemistry, Pergamon: Oxford, 1982, vol. 5, ch. 34.3.9, p. 162.

17 Barnes, C.E. in Abel, E.W.; Stone, F.G.A.; Wilkinson, G. (eds), Comprehensive Organometallic Chemistry II, Pergamon: Oxford, 1995, vol. 8, ch. 4.3.1.2, p. 423.

18 (a) Dellaca, R.J.; Penfold, B.R.; Robinson, B.H.; Robinson, W.T.; Spencer, J.L. Inorg. Chem., 1970, 9, 2204. (b) Dellaca, R.J.; Penfold, B.R. Inorg. Chem., 1971, 10, 1269.

19 Worth, G.H.; Robinson, B.R.; Simpson, J. Organometallics, 1992, 11, 501.

20 Seyferth, D.; Spohn, R.J.; Churchill, M.R.; Gold, K.; Scholer, F. J. ,Organomet. Chem., 1970, 23, 237. 
21 Antonova, A.B.; Bruce, M.I.; Ellis, B.G.; Gaudio, M.; Humphrey, P.A.; Jevric, M.; Melino, G.; Nicholson, B.K.; Perkins, G.J.; Skelton, B.W.; Stapleton, B.; White, A.H.; Zaitseva, N.N. Chem. Commun., 2004, 960.

22 (a) Downard, A.J.; Robinson, B.H.; Simpson, J. Organometallics, 1986, 5, 1122. (b) Downard, A.J.; Robinson, B.H.; Simpson, J. Organometallics, 1986, 5, 1132. (c) Downard, A.J.; Robinson, B.H.; Simpson, J. Organometallics, 1986, $5,1140$.

23 Aime, S.; Milone, L.; Valle, M. Inorg. Chim. Acta, 1976, 18, 9.

24 Yuan, P.; Richmond, M.G.; Schwarz, M. Inorg. Chem., 1990, 30, 679.

25 Hlavaty, J.; Kavan, L.; Sticha, M. J. Chem. Soc., Perkin Trans. 1, 2002, 705.

26 Bruce, M.I.; Skelton, B.W.; Smith, M.E.; White, A.H. Aust. J. Chem., 1999, $52,431$.

27 Bruce, M.I.; Kramarczuk, K.A.; Perkins, G.J.; Skelton, B.W.; White, A.H.; Zaitseva, N.N. J. Cluster Sci., 2004, 15, 119.

28 Balavoine, G.; Collin, J.; Bonnet, J.-J.; Lavigne, G. J. Organomet. Chem., 1985, 280, 429 .

29 Downard, A.J.; Robinson, B.H.; Simpson, J. J. Organomet. Chem., 1993, 447, 281.

30 Duffy, D.N.; Kassis, M.M.; Rae, A.D. Acta Crystallogr., 1991, C47, 2054.

31 Hong, F.-E; Huang, Y.-L.; Cheng, Y.-C.; Chu, K.-M. Appl. Organomet. Chem., 2003, 17, 458.

32 Seyferth, D.; Eschbach, C.S.; Nestle, M.O. J. Organomet. Chem., 1975, 97, C11.

33 Szafert, S.; Gladysz, J.A. Chem. Rev., 2003, 103, 4175.

34 Henderson, W.; McIndoe, J.S.; Nicholson, B.K.; Dyson, P.J. J. Chem. Soc., Dalton Trans., 1998, 519.

35 Bruce, M.I.; Nicholson, B.K.; bin Shawkataly, O. Inorg. Synth., 1989, 26, 325.

36 Cross, R.J.; Davidson, M.F. J. Chem. Soc., Dalton Trans., 1986, 411.

37 Bruce, M.I.; Horn, E.; Matisons, J.G.; Snow, M.R. Aust. J. Chem., 1984, 37, 1163. 
38 Whittall, I.R.; Humphrey, M.G.; Houbrechts, S.; Maes, J.; Persoons, A.; Schmid, S.; Hockless, D.C.R. J. Organomet. Chem., 1997, 544, 277.

39 Hall, S.R.; du Boulay, D.J.; Olthof-Hazekamp, R. (eds), The XTAL 3.7 System, University of Western Australia, 2000. 